\title{
Room-temperature Operation of Lithium Sulfide Positive and Silicon Negative Composite Electrodes Employing Oxide Solid Electrolytes for All-solid-state Battery
}

\section{Hiroshi NAGATA*, (10) and Junji AKIMOTO ${ }^{\S}$ (1)}

National Institute of Advanced Industrial Science and Technology (AIST), Central 5, 1-1-1 Higashi, Tsukuba, Ibaraki 305-8565, Japan

*Corresponding author: nagata.hiroshi@aist.go.jp

\section{ABSTRACT}

Oxide-type all-solid-state batteries are expected to be the next-generation batteries owing to their safety performance. Similarly, $\mathrm{Li}_{2} \mathrm{~S}$ and $\mathrm{Si}$ are also attracting attention as next-generation active materials owing to their high theoretical energy density. However, battery performances and manufacturing methods are associated with many challenges. Thus, this study focuses on an effective method for manufacturing $\mathrm{Li}_{2} \mathrm{~S}$ positive and $\mathrm{Si}$ negative composite electrodes for oxide-type all-solid-state $\mathrm{Li}_{2} \mathrm{~S}-\mathrm{Si}$ batteries. These composite electrodes are prepared via a one-step mechanical milling process using $\mathrm{Li}_{2} \mathrm{~S}$ or $\mathrm{Si}$ as the active materials, carbon with a high specific surface area, and raw materials of oxide glass electrolyte. A solid electrolyte (SE), as well as composites of the active materials, $\mathrm{SE}$, and carbon, are simultaneously generated via this process. Thereafter, the all-solid-state $\mathrm{Li}_{2} \mathrm{~S}-\mathrm{Si}$ full battery cell comprising $\mathrm{Li}_{2} \mathrm{~S}$ positive and $\mathrm{Si}$ negative composite electrodes, respectively, as prepared via the cold press technology, exhibits a relatively high energy density of $283 \mathrm{Wh} \mathrm{kg}^{-1}$ (sum of the masses of the positive and negative composite electrodes) and an area capacity of $4.0 \mathrm{mAh} \mathrm{cm}^{-2}$ at $0.064 \mathrm{mAcm}^{-2}$ and $25^{\circ} \mathrm{C}$.

(C) The Author(s) 2021. Published by ECSJ. This is an open access article distributed under the terms of the Creative Commons Attribution 4.0 License (CC BY, http://creativecommons.org/licenses/by/4.0/), which permits unrestricted reuse of the work in any medium provided the original work is properly cited. [DOI: 10.5796/electrochemistry.21-00112].

Keywords : Oxide Electrolyte, All-solid-state Battery, Full Battery Cell, $\mathrm{Li}_{2} \mathrm{~S}-\mathrm{Si}$ Battery

\section{Introduction}

All-solid-state lithium-ion batteries (LIBs) utilizing inorganic ${ }_{4}^{4}$ solid electrolytes (SEs) are being actively researched, and they have 5 demonstrated improved performances with time. Particularly, 6 batteries employing sulfide SEs, such as $\mathrm{Li}_{10} \mathrm{GeP}_{2} \mathrm{~S}_{12},{ }^{1} \mathrm{Li}_{7} \mathrm{P}_{3} \mathrm{~S}_{11},{ }^{2}$ and $\mathrm{Li}_{9.54} \mathrm{Si}_{1.74} \mathrm{P}_{1.44} \mathrm{~S}_{11.7} \mathrm{Cl}_{0.3},{ }^{3}$ exhibit relatively high performances 8 because of the high ionic conductivity and softness of sulfide SEs. 9 Conversely, the ionic conductivities of oxide $\mathrm{SEs}$, such as $\mathrm{Li}_{1.35}$ ${ }_{40} \mathrm{Al}_{0.35} \mathrm{Ge}_{0.2} \mathrm{Ti}_{1.45}\left(\mathrm{PO}_{4}\right)_{3},{ }^{4} \mathrm{Li}_{6.5} \mathrm{La}_{3} \mathrm{Zr}_{1.5} \mathrm{Nb}_{0.5} \mathrm{O}_{12},{ }^{5}$ and $\mathrm{Li}_{0.34} \mathrm{La}_{0.56} 6^{-}$ ${ }_{1} \mathrm{TiO}_{3},{ }^{6}$ are also improving with time, exhibiting a relatively high 2 ionic conductivity of $\sim 10^{-3} \mathrm{~S} \mathrm{~cm}^{-1}$, which is more than one order of 3 magnitude lower than those of organic electrolytes. Furthermore, 4 since it is challenging to form a Li-transfer path between particles 5 because crystalline oxide SEs exhibit low deformable property. 6 Thus, oxide-type all-solid-state LIBs exhibit low battery perform7 ances. ${ }^{7}$ However, oxide-type all-solid-state LIBs would represent an 8 ideal battery system if the battery performances can be improved 9 because they do not generate toxic gases like sulfide SEs.

Recently, it was reported that $\mathrm{Li}_{3} \mathrm{BO}_{3}-\mathrm{Li}_{2} \mathrm{SO}_{4}-\mathrm{Li}_{2} \mathrm{CO}_{3}, \mathrm{Li}_{2} \mathrm{CO}_{3}-$ $\mathrm{Li}_{3} \mathrm{BO}_{3}$, and $\mathrm{Li}_{2} \mathrm{SO}_{4}-\mathrm{Li}_{2} \mathrm{CO}_{3}$ systems with high deformability 2 provided good inter particle contact between the active material, 3 thereby demonstrating relatively high battery performance. ${ }^{8-10}$ ${ }_{4}$ Furthermore, we also reported the battery performances of a full 5 battery cell in an oxide-type all-solid-state $\mathrm{Li}_{2} \mathrm{~S}-\mathrm{Si}$ system with high 6 energy density and area capacity employing $\mathrm{Li}_{2} \mathrm{SO}_{4}-\mathrm{Li}_{2} \mathrm{CO}_{3}-\mathrm{LiX}$ 7 systems with excellent deformability and relatively high ionic 8 conductivity at $45^{\circ} \mathrm{C} .{ }^{11}$ Here, $\mathrm{Li}_{2} \mathrm{~S}$ and $\mathrm{Si}$ are known for high9 theoretical-capacity electrode active materials with specific capaci0 ties of 1166 and $4212 \mathrm{mAh} \mathrm{g}^{-1}$, respectively. ${ }^{12}$ Then, it reported 1 relatively high deformability and high ionic conductivity of $2>3 \times 10^{-5} \mathrm{~S} \mathrm{~cm}^{-1}$ for $\mathrm{Li}_{2} \mathrm{O}$-LiI systems. ${ }^{13}$ Based on the foregoing

${ }^{\S}$ ECSJ Active Member

H. Nagata (D) orcid.org/0000-0002-0390-6102

J. Akimoto (D) orcid.org/0000-0001-9636-7680 reports, it was considered that highly deformable oxide SEs could effectively improve the battery performances of all-solid-state LIBs by forming good inter particle contact. Moreover, we also reported the preparation of high-battery-performance positive and negative composite electrodes for sulfide-type all-solid-state $\mathrm{Li}_{2} \mathrm{~S}-\mathrm{Si}$ batteries via an effective one-step preparation method employing mechanical milling to accelerate the generation of SE employing activated carbon (AC) with a high specific area. ${ }^{13}$

This study focuses on improving the battery performances of $\mathrm{Li}_{2} \mathrm{~S}$ positive and $\mathrm{Si}$ negative composite electrodes for oxide-type all-solid-state $\mathrm{Li}_{2} \mathrm{~S}-\mathrm{Si}$ batteries. A one-step preparation method involving mechanical milling employing oxide SE raw materials was employed for the procedure. The half-battery cell comprising $\mathrm{Li}_{2} \mathrm{~S}$ positive and $\mathrm{Si}$ negative composite electrodes, which were prepared from raw materials of $\mathrm{Li}_{2} \mathrm{SO}_{4}-\mathrm{Li}_{2} \mathrm{CO}_{3}-\mathrm{LiX}$ and $\mathrm{Li}_{2} \mathrm{O}-\mathrm{LiI}$ systems, demonstrated relatively high capacities at 45 and $25^{\circ} \mathrm{C}$, respectively. Furthermore, the full battery cell comprising $\mathrm{Li}_{2} \mathrm{~S}$ positive and $\mathrm{Si}$ negative composite electrodes is demonstrated at $25^{\circ} \mathrm{C}$ operation and exhibited an energy density of $283 \mathrm{Wh} \mathrm{kg}^{-1}$ (sum of the masses of the positive and negative composite 50 electrodes) and an area capacity of $4.0 \mathrm{mAh} \mathrm{cm}^{-2}$ at $0.064 \mathrm{~mA} \mathrm{~cm}^{-2}$.

\section{Experimental}

Reagent-grade $\mathrm{Li}_{2} \mathrm{SO}_{4}$ (Sigma Aldrich, $99.99 \%$ ), $\mathrm{Li}_{2} \mathrm{CO}_{3}$ (Rare Metallic Corp., 99.99\%), LiBr (Sigma Aldrich, 99.999\%), LiI (Sigma Aldrich, $99.999 \%$ ), Li 2 O (Kojundo Chemical Lab. Co., Ltd., $99 \%$ ), $\mathrm{Li}_{2} \mathrm{~S}$ (Mitsuwa Chem., $99.9 \%$ ), Si (Niraco Co., 99.999\%), and AC (MSC-30, Kansai Coke and Chemicals Co., Ltd.) were used as starting materials for the positive and negative composite electrodes. Here, $\mathrm{Li}_{2} \mathrm{SO}_{4}, \mathrm{Li}_{2} \mathrm{CO}_{3}, \mathrm{Si}$, and $\mathrm{Li}_{2} \mathrm{O}$ were vacuum dried for $12 \mathrm{~h}$ at $300^{\circ} \mathrm{C}$ before the preparation of the composite electrode. The $\mathrm{Li}_{2} \mathrm{~S}$ positive and $\mathrm{Si}$ negative composite electrodes were prepared via mechanical milling employing a $\mathrm{ZrO}_{2}$ pot and $40 \mathrm{~g}$ of $5 \mathrm{~mm}$-diameter $\mathrm{ZrO}_{2}$ balls with a planetary ball-mill apparatus (Premium Line P-7, Fritsch Co.). The active materials $\left(\mathrm{Li}_{2} \mathrm{~S}\right.$ or $\mathrm{Si}$, 
Table 1. Weight ratios of the $\mathrm{Li}_{2} \mathrm{~S}$ and $\mathrm{Si}$ composite electrodes.

\begin{tabular}{ll}
\hline Sample name & \multicolumn{1}{c}{ Reagent ratio (weight) } \\
\hline $\mathrm{Li}_{2} \mathrm{~S}-\mathrm{LSCB}-\mathrm{AC}$ & $\mathrm{Li}_{2} \mathrm{~S}: \mathrm{Li}_{2} \mathrm{SO}_{4}: \mathrm{Li}_{2} \mathrm{CO}_{3}: \mathrm{LiBr}: \mathrm{AC}=30.0: 31.8: 14.2: 14.0: 10.0$ \\
$\mathrm{Si}-\mathrm{LSCI}-\mathrm{AC}$ & $\mathrm{Si}: \mathrm{Li}_{2} \mathrm{SO}_{4}: \mathrm{Li}_{2} \mathrm{CO}_{3}: \mathrm{LiI}: \mathrm{AC}=30.0: 25.9: 11.6: 22.5: 10.0$ \\
$\mathrm{Li}{ }_{2} \mathrm{~S}-\mathrm{LOI}-\mathrm{AC}$ & $\mathrm{Li}_{2} \mathrm{~S}: \mathrm{Li}_{2} \mathrm{O}: \mathrm{LiI}: \mathrm{AC}=30.0: 18.5: 41.5: 10.0$ \\
$\mathrm{Si}-\mathrm{LOI}-\mathrm{AC}$ & $\mathrm{Si}: \mathrm{Li}_{2} \mathrm{O}: \mathrm{LiI}: \mathrm{AC}=30.0: 18.5: 41.5: 10.0$ \\
\hline
\end{tabular}

$\mathrm{AC}$, and $\mathrm{SE}$ raw materials were composted in an Ar atmosphere at a rotational speed of $370 \mathrm{rpm}$ for $8 \mathrm{~h}^{11,14}$ The weight ratios of the active material for all the positive and negative composite electrodes were set to $30 \mathrm{wt} \%$, and those of the other components are displayed in Table 1. Here, composition formulae of LSCB, LSCI, and LOI were $0.45 \mathrm{Li}_{2} \mathrm{SO}_{4}-0.30 \mathrm{Li}_{2} \mathrm{CO}_{3}-0.25 \mathrm{LiBr}, 0.42 \mathrm{Li}_{2} \mathrm{SO}_{4}-0.28 \mathrm{Li}_{2} \mathrm{CO}_{3}-$ $0.30 \mathrm{LiI}$, and $0.67 \mathrm{Li}_{2} \mathrm{O}-0.33 \mathrm{LiI}$, respectively. Additionally, the ionic conductivities of LSCB, LSCI, and LOI prepared by mechanical milling following previous reports were $3.7,5.9$, and $16 \times 10^{-6}$ $\mathrm{S} \mathrm{cm}^{-1}$, respectively. ${ }^{11,13}$

X-ray diffraction (XRD, CuK $\alpha 1$, SmartLab II, Rigaku Co.) was employed to identify the residual crystalline phases in the $\mathrm{Li}_{2} \mathrm{~S}$ positive and Si negative composite electrodes. XRD was performed in a sealed cell that was assembled in an Ar-filled glove box for the evaluation in an $\mathrm{Ar}$ atmosphere, following our previous studies. ${ }^{11}$

The all-solid-state half- and full-battery cells were fabricated according to our previous reports. ${ }^{11}$ The half-battery cell structures comprised the $\mathrm{Li}_{2} \mathrm{~S}$ positive composite electrode/blended $\mathrm{SE}$ containing crystalline $\mathrm{Li}_{10} \mathrm{GeP}_{2} \mathrm{~S}_{12}$ and $80 \mathrm{Li}_{2} \mathrm{~S}-20 \mathrm{P}_{2} \mathrm{~S}_{5}$ glass (BSE) $\left(4.5 \mathrm{mS} \mathrm{cm}^{-1}\right)$ as the SE layer/Li-In alloy counter electrode and Si negative composite electrode $/ \mathrm{Li}_{3} \mathrm{PS}_{4}-\mathrm{LiI}\left(1.5 \mathrm{mS} \mathrm{cm}{ }^{-1}\right)$ as the SE layer/Li-In alloys. Here, the molar ratio of $\mathrm{Li} / \mathrm{In}$ in the counter 34 electrode was 0.64 , and the potential of the Li-In alloys was a 5 constant value $(0.62 \mathrm{~V}$ vs. $\mathrm{Li}) .{ }^{15} \mathrm{Next}, 10.0 \mathrm{mg}$ of the $\mathrm{Li}_{2} \mathrm{~S}$ positive composite electrode powder (or $5.0 \mathrm{mg}$ of the Si negative composite 7 electrode powder) and $80 \mathrm{mg}$ of $\mathrm{B}-\mathrm{SE}$ or $\mathrm{Li}_{3} \mathrm{PS}_{4}-\mathrm{LiI}$ powder were 8 placed in a $10-\mathrm{mm}$-inner-diameter ceramic tube and pressed by 9 stainless steel at $720 \mathrm{MPa}$ to form a two-layered pellet. Next, the Li4 In alloy counter electrode was formed by pressing a stack of $\mathrm{Li}$ and 4 In foil on the surface of the two-layered pellet, which was in contact 2 with $\mathrm{B}-\mathrm{SE}$ or $\mathrm{Li}_{3} \mathrm{PS}_{4}-\mathrm{LiI}$ at $80 \mathrm{MPa}$. The resulting three-layered pellet was subsequently sandwiched in two stainless-steel rods, 4 which acted as current collectors. Afterward, the full-battery cell ${ }_{5}$ structure comprising $\mathrm{Li}_{2} \mathrm{~S}$ positive composite electrode $/ \mathrm{Li}_{3} \mathrm{PS}_{4}-\mathrm{LiI}$ ${ }_{6} 6 \mathrm{SE}$ layer/Si negative composite electrode was obtained. Further, $710.0 \mathrm{mg}$ of the $\mathrm{Li}_{2} \mathrm{~S}$ positive composite electrode powder, $80 \mathrm{mg}$ of 8 the $\mathrm{Li}_{3} \mathrm{PS}_{4}-\mathrm{LiI}$ powder, and $5.0 \mathrm{mg}$ of the $\mathrm{Si}$ negative composite 9 electrode powder were placed in a 10 -mm-inner-diameter ceramic stube and pressed by the stainless steel at $720 \mathrm{MPa}$ to form a three1 layered pellet. The resulting three-layered pellet was subsequently 2 sandwiched in two stainless-steel rods, which acted as the current 3 collectors. Here, the half- and full-battery cells were assembled in an ${ }_{4}$ Ar-filled glove box and placed in a sealed vessel. The battery 5 performances of the $\mathrm{Li}_{2} \mathrm{~S}$ and $\mathrm{Si}$ half-battery cells and $\mathrm{Li}_{2} \mathrm{~S}-\mathrm{Si}$ full6 battery cells between $0.5-2.5,-0.6$ to 2.0 , and $0-3.0 \mathrm{~V}$, respectively, 7 were evaluated at a constant current density of $0.064-0.13 \mathrm{~mA} \mathrm{~cm}^{-2}$ 8 at 45 and $25^{\circ} \mathrm{C}$ employing a charge-discharge measuring device 9 (ACD-01, Asuka Electronics Co. Ltd.). Here, the discapacity of the Si half-battery cells was limited to $2500 \mathrm{mAh} \mathrm{g}^{-1}$ (Si) to prevent $\mathrm{Li}$ 1 dendrite growth and reduce cycle deterioration due to the volume 2 change of $\mathrm{Si}$.

\section{Results and Discussion}

The XRD patterns revealed that no crystalline phase was observed in $\mathrm{Li}_{2} \mathrm{~S}-\mathrm{LSCB}-\mathrm{AC}$ and $\mathrm{Si}-\mathrm{LSCI}-\mathrm{AC}$ that were prepared from the raw materials of the $\mathrm{Li}_{2} \mathrm{SO}_{4}-\mathrm{Li}_{2} \mathrm{CO}_{3}-\mathrm{LiX}$ systems other than crystalline active materials (Figs. 1a and $1 \mathrm{~b}$ ), and this indicated that the particles of the active materials were miniaturized during the process since their peaks were much broader than those of their starting materials. Furthermore, the result indicated that $\mathrm{Li}_{2} \mathrm{~S}$ was changed into an $\mathrm{Li}_{2} \mathrm{~S}-\mathrm{LiBr}$ solid solution since the XRD patterns of $\mathrm{Li}_{2} \mathrm{~S}$ in $\mathrm{Li}_{2} \mathrm{~S}-\mathrm{LSCB}-\mathrm{AC}$ were lower $2 \theta$ than that of the starting material of $\mathrm{Li}_{2} \mathrm{~S} .{ }^{16}$ Thus, it was assumed that both electrodes were prepared via the one-step process employing the active materials, $\mathrm{AC}$, and SE raw materials to simultaneously generate oxide $\mathrm{SE}$ and their composite, as observed in the one-step preparation of $\mathrm{Li}_{2} \mathrm{~S}$ and ${ }_{23}$ Si composite electrodes for sulfide systems. ${ }^{14}$

Figures $1 \mathrm{c}$ and $1 \mathrm{~d}$ show the charge-discharge curves of the 2 half-battery cells employing $\mathrm{Li}_{2} \mathrm{~S}-\mathrm{LSCB}-\mathrm{AC}$ and $\mathrm{Si}-\mathrm{LSCI}-\mathrm{AC}$ at 26 $0.064 \mathrm{~mA} \mathrm{~cm}^{-2}$ and $45^{\circ} \mathrm{C}$, respectively. $\mathrm{Li}_{2} \mathrm{~S}-\mathrm{LSCB}-\mathrm{AC}$ underwent 27 reversible charge-discharge reactions with capacities that gradually 28 increased with the increasing cycles from the 1 st to 5 th cycles, after 29 which it exhibited a discharge capacity of $848 \mathrm{mAh} \mathrm{g}^{-1}\left(\mathrm{Li}_{2} \mathrm{~S}\right)$ at the 30 5 th cycle. This improved capacity might be due to the improvement of the utilized $\mathrm{Li}_{2} \mathrm{~S}$ with the increasing cycles, as observed with the $\mathrm{Li}_{2} \mathrm{~S}$ positive composite electrode that was prepared from $0.45 \mathrm{Li}_{2-}$ $\mathrm{SO}_{4}-0.30 \mathrm{Li}_{2} \mathrm{CO}_{3}-0.25 \mathrm{LiBr}$ via a two-step process. ${ }^{11}$ However, the capacity was lower than those of the $\mathrm{Li}_{2} \mathrm{~S}$ positive composite 35 electrodes that were prepared via the two-step process. The low ionic conductivity of SE in $\mathrm{Li}_{2} \mathrm{~S}-\mathrm{LSCB}-\mathrm{AC}$ might be due to the decreasing ratio of $\mathrm{LiBr}$ in $\mathrm{SE}$ since the reaction for generating $\mathrm{SE}$ competes with the generation of the $\mathrm{Li}_{2} \mathrm{~S}-\mathrm{LiBr}$ solid solution. Conversely, the capacities of Si-LSCI-AC gradually increased with the increasing cycles from the 1 st to 5 th cycles and exhibited a 4 charge capacity of $2490 \mathrm{mAhg}^{-1}(\mathrm{Si})$, which was an almost 42 controlled capacity, in the 5 th cycle. This performance was much 4 similar to that of the two-step-prepared electrode. ${ }^{11}$ It was assumed 44 that $0.42 \mathrm{Li}_{2} \mathrm{SO}_{4}-0.28 \mathrm{Li}_{2} \mathrm{CO}_{3}-0.30 \mathrm{LiI}$ was generated via the one- 45 step process since $\mathrm{Si}$, dissimilar to $\mathrm{Li}_{2} \mathrm{~S}$, did not compete with the 46 generation of the solid solution. Further, Figs. 1e and 1f show the 47 charge-discharge curves of the half-battery cells employing $\mathrm{Li}_{2} \mathrm{~S}-48$ LSCB-AC and Si-LSCI-AC at $0.064 \mathrm{~mA} \mathrm{~cm}^{-2}$ and $25^{\circ} \mathrm{C}$, respectively. The capacities of $\mathrm{Li}_{2} \mathrm{~S}-\mathrm{LSCB}-\mathrm{AC}$ increased with the increasing cycles from the 1 st to 5 th cycles, exhibiting a discharge capacity of $547 \mathrm{mAh} \mathrm{g}^{-1}\left(\mathrm{Li}_{2} \mathrm{~S}\right)$ in the 5th cycle. However, the 5 capacity was much lower because of the lower ionic conductivity of 53 $\mathrm{SE}$ and the reactivity of $\mathrm{Li}_{2} \mathrm{~S}$ at $25^{\circ} \mathrm{C}$ than at $45^{\circ} \mathrm{C}$. Contrarily, the 54 performances of Si-LSCI-AC were similar at $25^{\circ} \mathrm{C}$ and $45^{\circ} \mathrm{C} 55$ where the overvoltage is slightly large. These differences between 56 the $\mathrm{Li}_{2} \mathrm{~S}$ and $\mathrm{Si}$ composite electrodes were caused by the different ${ }_{57}$ conductivities of $\mathrm{Li}_{2} \mathrm{~S}$ and $\mathrm{Si}$. Therefore, it is important to improve 58 the performance of the positive composite electrode since it would 59 strongly influence the performance of the $\mathrm{Li}_{2} \mathrm{~S}-\mathrm{Si}$ full-battery cell.

Next, the raw materials of $\mathrm{Li}_{2} \mathrm{O}-\mathrm{LiI}$ systems were investigated 6 as the starting materials to improve the ionic conductivities of the 62 positive and negative composite electrodes. Figures $2 \mathrm{a}$ and $2 \mathrm{~b}$ show 63 the XRD patterns of $\mathrm{Li}_{2} \mathrm{~S}-\mathrm{LOI}-\mathrm{AC}$ and $\mathrm{Si}-\mathrm{LOI}-\mathrm{AC}$, respectively. 64 $\mathrm{Li}_{2} \mathrm{~S}$ with the low $2 \theta$ value corresponds to the $\mathrm{Li}_{2} \mathrm{~S}-\mathrm{LiI}$ solid 65 solution, and the $\mathrm{Li}_{2} \mathrm{O}$ phases were detected in the XRD patterns of 66 

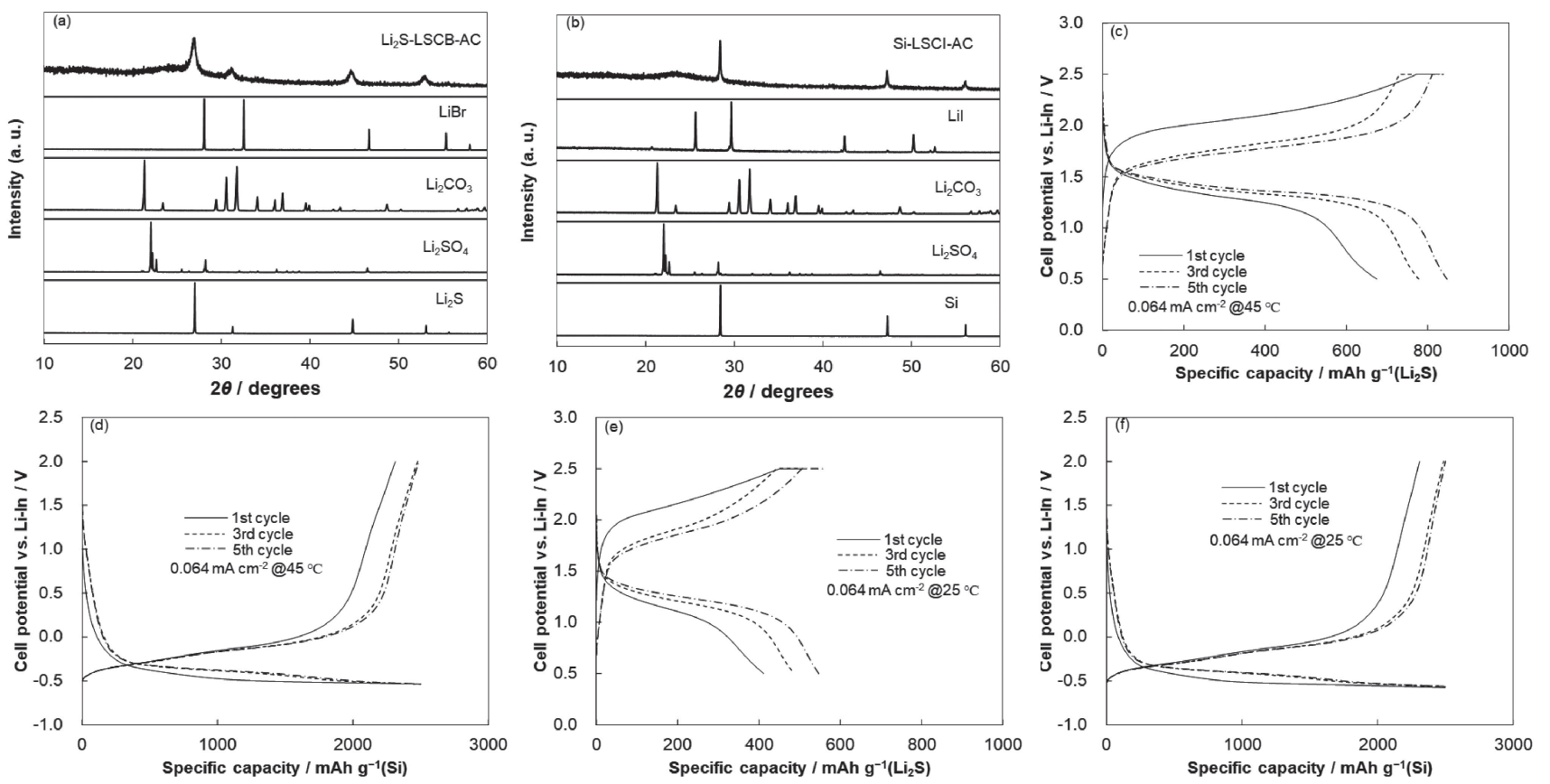

Figure 1. XRD patterns of (a) $\mathrm{Li}_{2} \mathrm{~S}-\mathrm{LSCB}-\mathrm{AC}$ and (b) Si-LSCI-AC. Charge-discharge curves of the (c, e) $\mathrm{Li}_{2} \mathrm{~S}-\mathrm{LSCB}-\mathrm{AC}$ and (d, f) Si- 24 LSCI-AC half-battery cells at $0.064 \mathrm{~mA} \mathrm{~cm}^{-2}$ at 45 and $25^{\circ} \mathrm{C}$.
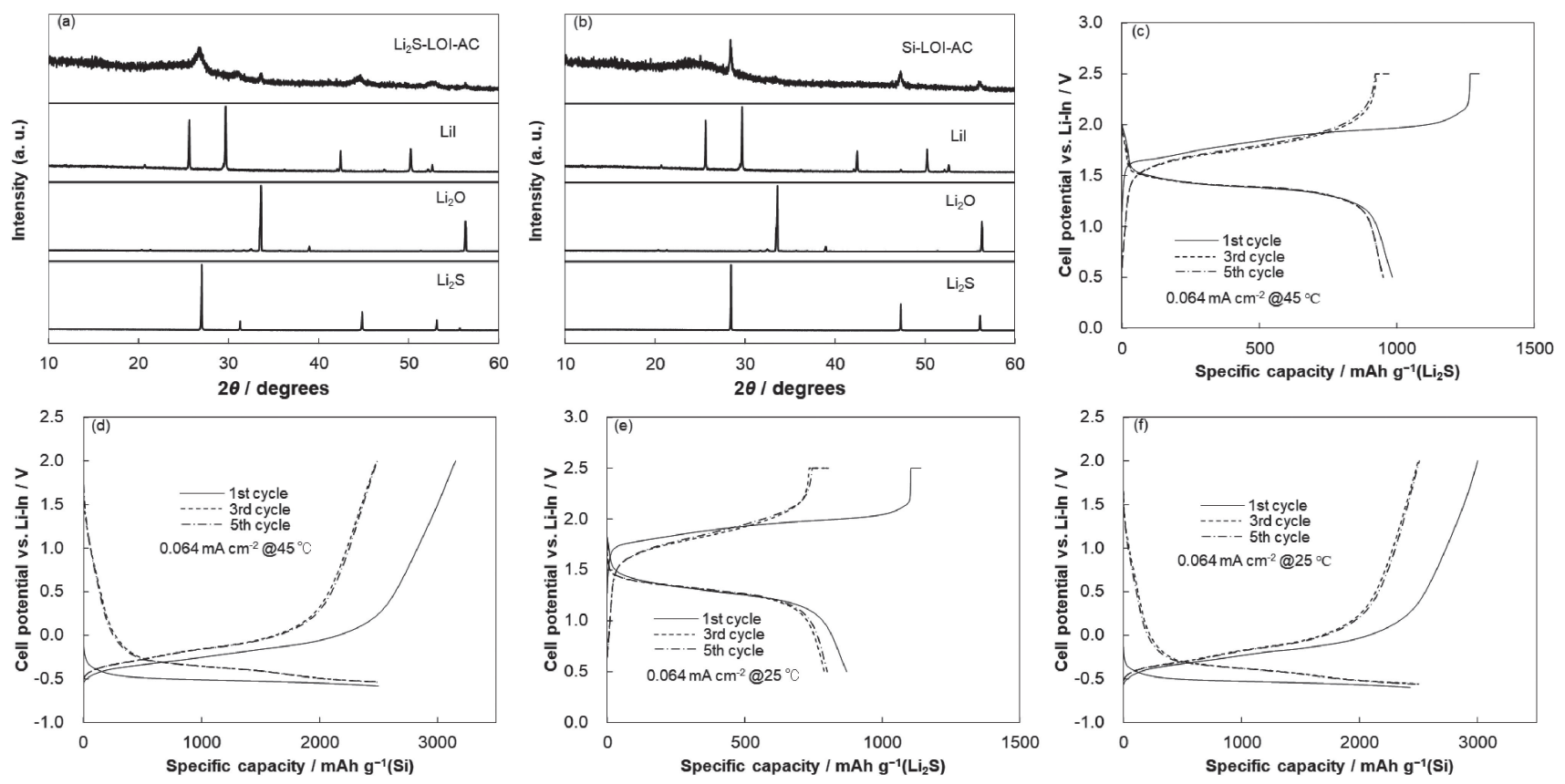

Figure 2. XRD patterns of (a) $\mathrm{Li}_{2} \mathrm{~S}-\mathrm{LOI}-\mathrm{AC}$ and (b) Si-LOI-AC. Charge-discharge curves of the (c, e) $\mathrm{Li}_{2} \mathrm{~S}-\mathrm{LOI}-\mathrm{AC}$ and (d, f) Si-LOI- 5 AC half-battery cells at $0.064 \mathrm{~mA} \mathrm{~cm}^{-2}$ at 45 and $25^{\circ} \mathrm{C}$.

$\mathrm{Li}_{2} \mathrm{~S}-\mathrm{LOI}-\mathrm{AC}$, indicating that the $\mathrm{Li}_{2} \mathrm{O}$ phase remained because the 6 ratio of LiI was reduced via the generation of the $\mathrm{Li}_{2} \mathrm{~S}-\mathrm{LiI}$ solid 7 solution and was out of the range of the $\mathrm{Li}_{2} \mathrm{O}-\mathrm{LiI}$ solid solution. 8 Contrarily, the XRD patterns of Si-LOI-AC revealed only the Si 9 crystalline phase without the $\mathrm{Li}_{2} \mathrm{O}$ and LiI phases. Thus, it was 0 assumed that it remained in the solid-solution range of the $\mathrm{Li}_{2} \mathrm{O}-\mathrm{LiI}$ 1 systems in $\mathrm{Si}-\mathrm{LOI}-\mathrm{AC}$.

Figures $2 \mathrm{c}$ and $2 \mathrm{~d}$ show the charge-discharge curves of the 3 half-battery cells employing $\mathrm{Li}_{2} \mathrm{~S}-\mathrm{LOI}-\mathrm{AC}$ and $\mathrm{Si}-\mathrm{LOI}-\mathrm{AC}$ at ${ }^{4} 0.064 \mathrm{~mA} \mathrm{~cm}^{-2}$ and $45^{\circ} \mathrm{C}$, respectively. $\mathrm{Li}_{2} \mathrm{~S}-\mathrm{LOI}-\mathrm{AC}$ exhibited a 5 lower overvoltage and a higher capacity than $\mathrm{Li}_{2} \mathrm{~S}-\mathrm{LSCB}-\mathrm{AC}$, 6 indicating that the resistance of the positive composite electrode was reduced by the high ionic conductivity of the $\mathrm{Li}_{2} \mathrm{O}-\mathrm{LiI}$ systems. 55 However, an irreversible oxidation capacity of about $270 \mathrm{mAh} \mathrm{g}^{-1} 56$ $\left(\mathrm{Li}_{2} \mathrm{~S}\right)$ was observed in the 1 st cycle, and it corresponds to the 57 oxidation of LiI in the solid-solution component. Thereafter, the 58 charge and discharge capacities were about $950 \mathrm{mAh} \mathrm{g}^{-1}\left(\mathrm{Li}_{2} \mathrm{~S}\right)$ with 59 coulombic efficiencies of $>97 \%$ from the 2 nd to 5 th cycles. Thus, it 60 was assumed that the oxidation of SE in the positive composite 61 electrode proceeded mainly during the 1 st charge cycle. Conversely, 62 the discharge and charge capacities of Si-LOI-AC in the 1st cycle 63 were 2500 and $3150 \mathrm{mAh} \mathrm{g}^{-1}(\mathrm{Si})$, respectively, indicating a higher 64 charge capacity than the discharge one. Furthermore, the 1 st 65 discharge potential of $\mathrm{Si}-\mathrm{LOI}-\mathrm{AC}$ was much lower than that of 66 

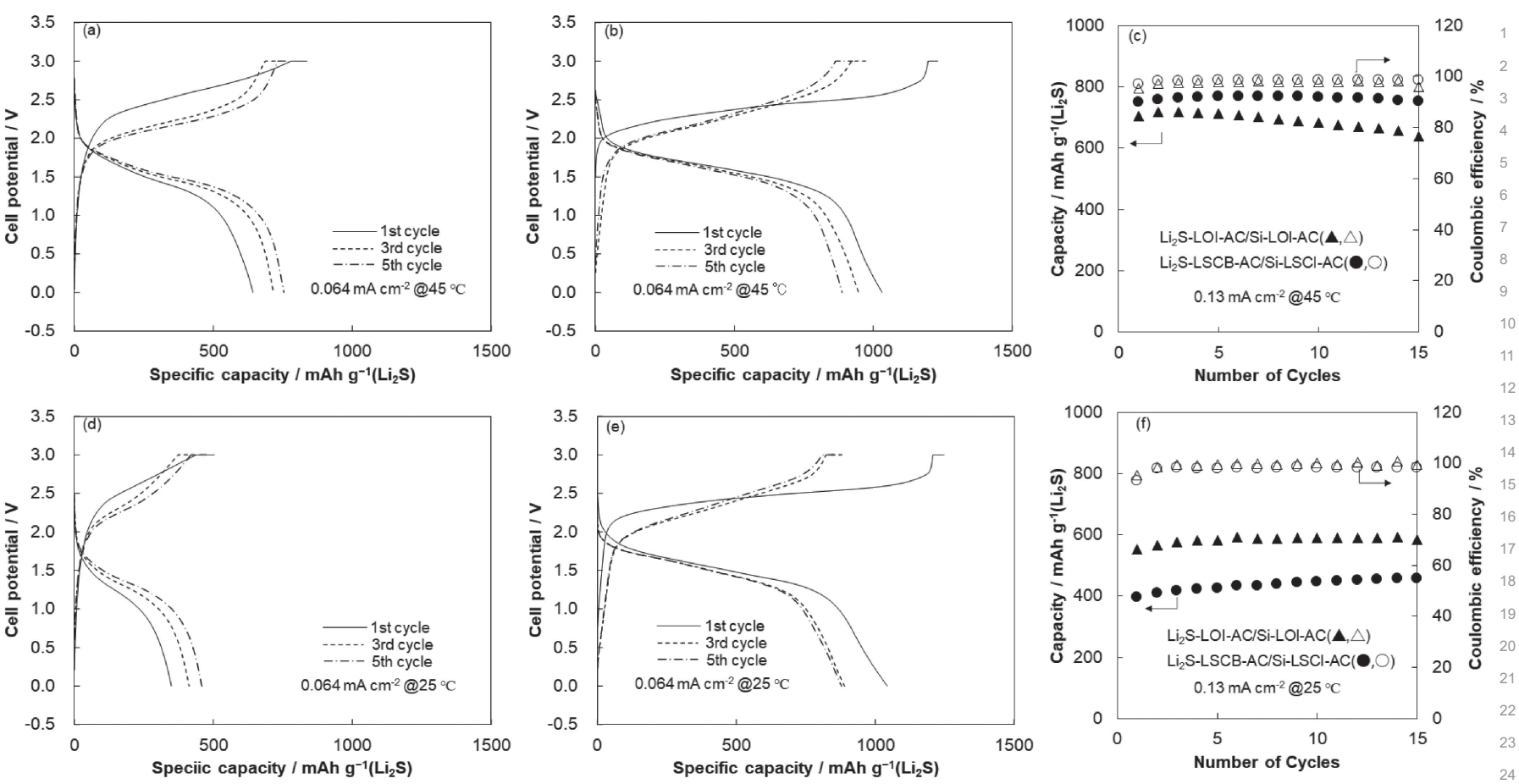

Figure 3. Charge-discharge curves of the (a, d) $\mathrm{Li}_{2} \mathrm{~S}-\mathrm{LSCB}-\mathrm{AC} / \mathrm{Si}-\mathrm{LSCI}-\mathrm{AC}$ and $(\mathrm{b}, \mathrm{e}) \mathrm{Li} 2 \mathrm{~S}-\mathrm{LOI}-\mathrm{AC} / \mathrm{Si}-\mathrm{LOI}-\mathrm{AC}$ full-battery cells at $0.064 \mathrm{~mA} \mathrm{~cm}^{-2}$ at 45 and $25^{\circ} \mathrm{C}$. Cycling performances of the (c) $\mathrm{Li}_{2} \mathrm{~S}-\mathrm{LSCB}-\mathrm{AC} / \mathrm{Si}-\mathrm{LSCI}-\mathrm{AC}$ and (f) $\mathrm{Li}_{2} \mathrm{~S}-\mathrm{LOI}-\mathrm{AC} / \mathrm{Si}-\mathrm{LOI}-\mathrm{AC}$ fullbattery cells at $0.13 \mathrm{~mA} \mathrm{~cm}^{-2}$ at 45 and $25^{\circ} \mathrm{C}$.

Si-LSCI-AC, indicating that there were Li-Si alloys or other 2 lithiated products owing to the reaction between $\mathrm{Si}$ and $\mathrm{Li}_{2} \mathrm{O}$ during 3 the mechanical milling of Si-LOI-AC. Subsequently, the discharge 34 and charge capacities were stable at about $2500 \mathrm{mAhg}^{-1}(\mathrm{Si})$ 5 (controlled value) with coulombic efficiencies of $>99 \%$ at the 2 nd ${ }^{6}$ 5th cycles. Furthermore, Figs. 2e and $2 \mathrm{f}$ show the charge-discharge 37 curves of the half-battery cells employing $\mathrm{Li}_{2} \mathrm{~S}-\mathrm{LOI}-\mathrm{AC}$ and $\mathrm{Si}-$ 3 LOI-AC at $0.064 \mathrm{~mA} \mathrm{~cm}^{-2}$ and $25^{\circ} \mathrm{C}$, respectively. These capacities 9 are slightly lower than those at $45^{\circ} \mathrm{C}$. However, the capacity of ${ }_{4} \mathrm{Li}_{2} \mathrm{~S}-\mathrm{LOI}-\mathrm{AC}$ was much higher than that of $\mathrm{Li}_{2} \mathrm{~S}-\mathrm{LSCB}-\mathrm{AC}$ at ${ }_{4} 25^{\circ} \mathrm{C}$ because of the high ionic conductivity of the $\mathrm{Li}_{2} \mathrm{O}-\mathrm{LiI}$ system. 2 Next, Si-LOI-AC and Si-LSCI-AC exhibited similar reversible 3 capacities from the 2 nd to the 5 th cycles. Thus, it was assumed that 4 the electrodes employing low-reactive active materials, such as $\mathrm{Li}_{2} \mathrm{~S}$, 5 were more sensitive for the ionic conductivity of SE than high electroconductive active materials, such as Si.

Finally, the charge-discharge performances of the full-battery 8 cells for $\mathrm{Li}_{2} \mathrm{~S}-\mathrm{LSCB}-\mathrm{AC} / \mathrm{Si}-\mathrm{LSCI}-\mathrm{AC}$ and $\mathrm{Li}_{2} \mathrm{~S}-\mathrm{LOI}-\mathrm{AC} / \mathrm{Si}-$ 9 LOI-AC were demonstrated. Figures $3 \mathrm{a}$ and $3 \mathrm{~b}$ show the chargedischarge curves of the full-battery cells of $\mathrm{Li}_{2} \mathrm{~S}-\mathrm{LSCB}-\mathrm{AC} / \mathrm{Si}-$ 1 LSCI-AC and $\mathrm{Li}_{2} \mathrm{~S}-\mathrm{LOI}-\mathrm{AC} / \mathrm{Si}-\mathrm{LOI}-\mathrm{AC}$ at $0.064 \mathrm{~mA} \mathrm{~cm}^{-2}$ and $245^{\circ} \mathrm{C}$, respectively. The capacities of $\mathrm{Li}_{2} \mathrm{~S}-\mathrm{LSCB}-\mathrm{AC} / \mathrm{Si}-\mathrm{LSCI}-$ $3 \mathrm{AC}$ increased gradually with the increasing cycles from the 1 st to ${ }_{4} 5$ th cycles by increasing utilization of $\mathrm{Li}_{2} \mathrm{~S}$. Thereafter, it exhibited a 5 discharge capacity of $754 \mathrm{mAh} \mathrm{g}^{-1}\left(\mathrm{Li}_{2} \mathrm{~S}\right)$, which was similar to the 6 half-battery cell of $\mathrm{Li}_{2} \mathrm{~S}-\mathrm{LSCB}-\mathrm{AC}$ in the 5 th cycle. However, the 7 first discharge capacity was smaller than that of the half battery cell 8 of $\mathrm{Li}_{2} \mathrm{~S}-\mathrm{LSCB}-\mathrm{AC}$ because the delithiation potential of $\mathrm{Si}$ was 9 limited to $0.5-1.0 \mathrm{~V}$ (vs. Li-In) under discharge test conditions of 0 the $\mathrm{Li}_{2} \mathrm{~S}-\mathrm{Si}$ full-battery cell. Conversely, $\mathrm{Li}_{2} \mathrm{~S}-\mathrm{LOI}-\mathrm{AC} / \mathrm{Si}-\mathrm{LOI}-$ $1 \mathrm{AC}$ exhibited similar first discharge capacity of half battery cell of $2 \mathrm{Li}_{2} \mathrm{~S}-\mathrm{LOI}-\mathrm{AC}$ because the potential of the negative electrode was 33 low owing to the large irreversible charge capacity of $\mathrm{Li}_{2} \mathrm{~S}-\mathrm{LOI}-\mathrm{AC}$ 64 and the existence of the Li-Si alloy in Si-LOI-AC. However, the 5 capacities were reduced with the increasing number of cycles 66 probably because the oxidation of $\mathrm{LiI}$ in $\mathrm{Si}-\mathrm{LOI}-\mathrm{AC}$ proceeded with the increasing number of cycles, thereby reducing the ionic conductivity of SE. Further, the cycling performances of $\mathrm{Li}_{2} \mathrm{~S}-32$ LSCB-AC/Si-LSCB-AC and $\mathrm{Li}_{2} \mathrm{~S}-\mathrm{LOI}-\mathrm{AC} / \mathrm{Si}-\mathrm{LOI}-\mathrm{AC}$ at 33 $0.13 \mathrm{~mA} \mathrm{~cm}^{-2}$ and $45^{\circ} \mathrm{C}$ are shown in Fig. $3 \mathrm{c} . \mathrm{Li}_{2} \mathrm{~S}-\mathrm{LSCB}-\mathrm{AC} / 34$ Si-LSCI-AC exhibited a discharge capacity of $753 \mathrm{mAh} \mathrm{g}^{-1}\left(\mathrm{Li}_{2} \mathrm{~S}\right) 35$ in the 15th cycle, and this value corresponds to the result of the low 36 current density test since it continued to improve the utilization of 37 $\mathrm{Li}_{2} \mathrm{~S}$. Dissimilarly, the cycling capacity of $\mathrm{Li}_{2} \mathrm{~S}-\mathrm{LOI}-\mathrm{AC} / \mathrm{Si}-\mathrm{LOI}-38$ $\mathrm{AC}$ reduced with the increasing number of cycles to $638 \mathrm{mAh} \mathrm{g}^{-1} 39$ $\left(\mathrm{Li}_{2} \mathrm{~S}\right)$ in the 15 th cycle. The capacities of $\mathrm{Li}_{2} \mathrm{~S}-\mathrm{LOI}-\mathrm{AC} / \mathrm{Si}-\mathrm{LOI}-40$ AC were lower than those of $\mathrm{Li}_{2} \mathrm{~S}-\mathrm{LSCB}-\mathrm{AC} / \mathrm{Si}-\mathrm{LSCI}-\mathrm{AC}$ despite 41 its higher initial capacity at $0.064 \mathrm{~mA} \mathrm{~cm}^{-2}$ at $45^{\circ} \mathrm{C}$. This is 42 probably because the oxidation of $\mathrm{LiI}$ in $\mathrm{Li}_{2} \mathrm{~S}-\mathrm{LOI}-\mathrm{AC}$ proceeded 43 further and reduced the ionic conductivity. Figures $3 \mathrm{~d}$ and $3 \mathrm{e}$ show 44 their charge-discharge curves at $0.064 \mathrm{~mA} \mathrm{~cm}^{-2}$ and $25^{\circ} \mathrm{C} .45$ Regarding $\mathrm{Li}_{2} \mathrm{~S}-\mathrm{LSCB}-\mathrm{AC} / \mathrm{Si}-\mathrm{LSCI}-\mathrm{AC}$, the capacities increased 46 with the increasing number of cycles, although it was much lower 47 than that at $45^{\circ} \mathrm{C}$ because the ionic conductivity of the positive 48 composite electrode decreased with the decreasing temperature 49 (Fig. 3d). Conversely, $\mathrm{Li}_{2} \mathrm{~S}-\mathrm{LOI}-\mathrm{AC} / \mathrm{Si}-\mathrm{LOI}-\mathrm{AC}$ exhibited a first 50 discharge capacity of $1043 \mathrm{mAh} \mathrm{g}^{-1}\left(\mathrm{Li}_{2} \mathrm{~S}\right)$ at $25^{\circ} \mathrm{C}$, which close to 51 that of $45^{\circ} \mathrm{C}$, because of the high ionic conductivity of $\mathrm{Li}_{2} \mathrm{O}-\mathrm{LiI} 52$ systems. From the average voltage $(1.36 \mathrm{~V})$ and capacity at the first 53 discharge at $0.064 \mathrm{~mA} \mathrm{~cm}^{-2}$ and $25^{\circ} \mathrm{C}$, it was calculated a relatively 54 high energy density of $283 \mathrm{Wh} \mathrm{kg}^{-1}$ (the sum of the masses of the 55 positive and negative composite electrodes) and an area capacity 56 of $4.0 \mathrm{mAh} \mathrm{cm}^{-2}$. Incidentally, the energy density of the test cell 57 including weight of SE layer was $45 \mathrm{Wh} \mathrm{kg}^{-1}$ (the sum of the masses 58 of the positive, negative composite electrodes, and SE layer) that 59 dramatically changes by preparation of full-battery cell construction, 60 such as thickness of SE layer. Thus, it is possible to consider the 61 quality of performance by considering based on the weight of the 62 positive and negative electrodes and electrode area when discussing 63 the energy density and area capacity of a full-battery cells. The 64 performance was higher than those of recently researched sulfide- 65 type Li-S batteries. ${ }^{17}$ Moreover, their cycling performances at 66 
$10.13 \mathrm{~mA} \mathrm{~cm}^{-2}$ and $25^{\circ} \mathrm{C}$ are shown in Fig. 3 f. $\mathrm{Li}_{2} \mathrm{~S}-\mathrm{LOI}-\mathrm{AC} / \mathrm{Si}-$ 2 LOI-AC exhibited a higher capacity than $\mathrm{Li}_{2} \mathrm{~S}-\mathrm{LSCB}-\mathrm{AC} / \mathrm{Si}-$ 3 $\mathrm{LSCB}-\mathrm{AC}$ until the 15 th cycles, dissimilar to the test at $45^{\circ} \mathrm{C}$; this 4 indicated that the ionic conductivity of $\mathrm{Li}_{2} \mathrm{~S}-\mathrm{LOI}-\mathrm{AC}$ was still high 5 because the oxidation of LiI was slower at $25^{\circ} \mathrm{C}$ than at $45^{\circ} \mathrm{C}$. Regarding $\mathrm{Li}_{2} \mathrm{~S}-\mathrm{LSCB}-\mathrm{AC} / \mathrm{Si}-\mathrm{LSCB}-\mathrm{AC}$, the capacity increased with the increasing cycles, indicating the improved utilization of $\mathrm{Li}_{2} \mathrm{~S}$ during the cycles.

The above results demonstrated the possibility of achieving a high-energy-density oxide-type all-solid-state $\mathrm{Li}_{2} \mathrm{~S}-\mathrm{Si}$ battery and an effective method for preparing composite electrodes.

\section{Conclusions}

This paper reports a one-step method for preparing $\mathrm{Li}_{2} \mathrm{~S}$-positive and Si-negative composite electrodes for an oxide-type all-solidstate $\mathrm{Li}_{2} \mathrm{~S}-\mathrm{Si}$ battery and the battery performances of the full battery cells employing these positive and negative composite electrodes at $25^{\circ} \mathrm{C}$. The battery performances were greatly improved by improving the potential profile gap between positive and negative electrodes, which was due to the partially lithiated $\mathrm{Si}$ negative composite electrode. Further, the oxide-type all-solid-state $\mathrm{Li}_{2} \mathrm{~S}-\mathrm{Si}$ full battery cell exhibited a relatively high energy density of $283 \mathrm{Wh} \mathrm{kg}^{-1}$ (sum of the masses of the positive and negative composite electrodes) and an area capacity of $4.0 \mathrm{mAh} \mathrm{cm}^{-2}$ at $0.064 \mathrm{~mA} \mathrm{~cm}^{-2}$ and $25^{\circ} \mathrm{C}$.

\section{CRediT Authorship Contribution Statement}

Hiroshi Nagata: Conceptualization (Lead)

Junji Akimoto: Supervision (Supporting)

\section{Conflict of Interest}

The authors declare no conflict of interest in the manuscript.

\section{References}

1. N. Kamaya, K. Homma, Y. Yamakawa, M. Hirayama, R. Kanno, M. Yonemura, T. 7 Kamiyama, Y. Kato, S. Hama, K. Kawamoto, and A. Mitsui, Nat. Mater., 10, 682 (2011).

2. Y. Seino, T. Ota, K. Takada, A. Hayashi, and M. Tatsumisago, Energy Environ. Sci., 7, 627 (2014).

3. Y. Kato, S. Hori, T. Saito, K. Suzuki, M. Hirayama, A. Mitsui, M. Yonemura, H. 1 Iba, and R. Kanno, Nat. Energy, 1, 16030 (2016).

4. F. Bai, D. Mori, S. Taminato, Y. Takeda, O. Yamamoto, H. Nemori, M. Nomura, and N. Imanishi, Solid State Ionics, 345, 115151 (2020).

5. K. Kataoka, H. Nagata, and J. Akimoto, Sci. Rep., 8, 9965 (2018).

6. Y. Harada, T. Ishigaki, H. Kawai, and J. Kuwano, Solid State Ionics, 108, 40715 (1998).

7. D. Wang, C. Zhu, Y. Fu, X. Sun, and Y. Yang, Adv. Energy Mater, 10, 2001318 (2020).

8. K. Nagao, A. Sakuda, A. Hayashi, and M. Tatsumisago, J. Power Sources, 424, 215 (2019).

9. T. Okumura, T. Takeuchi, and H. Kobayashi, Solid State Ionics, 288, 248 (2016). 20

10. H. Nagata and J. Akimoto, J. Power Sources, 491, 229620 (2021).

11. H. Nagata and J. Akimoto, ACS Appl. Mater. Interfaces, 13, 35785 (2021).

12. Y. Yang, M. T. McDowell, A. Jackson, J. J. Cha, S. S. Hong, and Y. Cui, Nano Lett., 10, 1486 (2010).

13. Y. Fujita, Y. Kawasaki, T. Inaoka, T. Kimura, A. Sakuda, M. Tatsumisago, and A. 24 Hayashi, Electrochemistry, 89, 334 (2021).

14. H. Nagata and J. Akimoto, J. Electrochem. Soc., 168, 090557 (2021)

15. K. Takada, N. Aotani, K. Iwamoto, and S. Kondo, Solid State Ionics, 86-88, 877 (1996).

16. T. Hakari, A. Hayashi, and M. Tatsumisago, Adv. Sustain. Syst., 1, 170001728 (2017).

17. J. Wu, S. Liu, F. Han, X. Yao, and C. Wang, Adv. Mater., 33, 2000751 (2021). 30 